\title{
O ATOR-ESTÁTUA DIANTE DO ESPELHO
}

\section{L'acteur-statue dans l'oeil du miroir}

\author{
Monique Borie
}

Université Paris 3

Tradução: José Tonezzi

Resumo: Esta reflexão traça aproximações entre o pensamento e a escrita de Jean Genet com a obra do escultor Alberto Giacometti. A partir de referências objetivas, busca-se detectar o trabalho escultórico na constituição de uma obra escrita, cujo propósito maior é sobrepor o papel do ator às funções de uma escultura que transcende a forma.

Palavras-chave: Jean Genet; Giacometti; Gesto poético; Escrita cênica.

Résumé: Cette réflexion dessine des approximations entre la pensée et l'écriture de Jean Genet avec l'œuvre du sculpteur Alberto Giacometti. À partir de références objectives, on cherche à détecter le travail sculptural dans la constitution d'une œuvre écrite, dont le but plus important est de superposer le rôle de l'acteur aux fonctions d'une sculpture qui transcende la forme.

Mots-clés: Jean Genet; Giacometti; Geste poétique; Écriture scénique. 
"Um gesto poético é um gesto que abre uma noite, que redimensiona as coisas do dia"... "não ter medo de entrar na noite". Com tais frases, extraídas de seu livro $L e$ danseur des solitudes, Georges DidiHuberman (2006, p. 67 e 74), melhor do que qualquer outro, nos permite apresentar a questão do ator em Genet.

O ator idealizado por Genet é, efetivamente, aquele capaz de alcançar a dimensão do gesto poético, sem medo de entrar na noite. Para tanto, Genet lhe oferece como horizonte um modelo dualizado: o gesto de um escultor e o gesto de um dançarino - a estátua e o funâmbulo. Ambos traçam para o ator um caminho na direção de um "signo, figura inalterável cujo conteúdo final é a morte" (GENET, 1990, p. 71), que deve se cristalizar como seu alvo. "Signo, carregado de significados" é, no grande lamento de Genet, o que o ator ocidental se recusa a ser, esse ator no qual ele condena o fechamento na identificação com um personagem, num teatro que busca reproduzir de maneira muito exata o mundo visível, que imita as ações dos homens, que não é capaz de criar "símbolos ativos"1.

Em sua abordagem da obra de Giacometti pode-se ter um melhor entendimento do que propõe Genet, percebendo-se que se desenvolve um grande jogo de ressonâncias entre 0 seu texto sobre 0 escultor e seus textos sobre o ator em relação ao teatro que este deve compor. A aventura teatral a que Genet aspira condiz e se vincula à aventura de Giacometti.

1 Cf. "Lettre à Jean Jacques Pauvert" in Fragments (GENET, 1990, p. 101 à 103) para este processo do ator ocidental.
Genet se reconhece na aventura do escultor, uma aventura "capaz de se desfazer da aparência visível", para ir "além do mensurável" (GENET, 1979 p. 41). Uma aventura livre de falsas semblanças utilitárias, capaz então de "desproporcionar as coisas do dia". Para acessar a "imobilidade soberana" (p. 43) de uma imagem visível, que conduz a um lugar misterioso, alhures, além. Um lugar que se remete às profundezas do tempo, à origem de tudo, ao tempo imemorial daquela noite original e fundadora, que é a noite dos mortos.

É esta a noite que abre o gesto do escultor, noite de onde saem estátuas que parecem provenientes da morte e se destinam aos mortos, indo para eles. "Giacometti não trabalha para seus contemporâneos", diz Genet, "nem para as gerações vindouras: ele faz estátuas que por fim exaltam os mortos" (GENET, 1979, p. 72). Em Lettres à Roger Blin, é bem uma celebração destinada aos mortos que o gesto do homem de teatro deve criar, um gesto cuja força de "deflagração poética" deve ser capaz de "iluminar o mundo dos mortos", de "romper o que nos separa dos mortos" (GENET, 1968, p. 221). Este modelo de teatro não está em buscar na vida real, mas na "vida poética", "diz aquilo que por vezes se descobre nos confins da morte "(p. 224). Somente a poesia em sua relação com a noite pode dar ao ato teatral essa gravidade que permitirá que 0 ator chegue "à beira do ato definitivo" (p. 258). Uma gravidade que precisa de um pouco de trevas, como lembra Genet em L'étrange mot d' (GENET, 1968), em que o teatro no cemitério fornece a metáfora. 
Para Genet, portanto, a estética da cena deve excluir qualquer referência à vida, às coisas do dia. Assim como, no início do século XX, Gordon Craig reivindicava para o ator a referência à gravidade, à solenidade de uma beleza da morte, em oposição à vida no sentido dos realistas, uma beleza em que a estatuária oferecia precisamente o modelo (CRAIG, 1999), da mesma forma Genet, ansioso por livrar o ator da tentação do cotidiano, imagina para ele uma beleza da morte - mas ele o faz em termos muito diferentes daqueles de Craig. Certamente ele imagina para o ator uma voz e um gestual visando o além, mas para "desmesurar" de alguma forma 0 corpo vivo e diurno do ator ele propõe um uso bem particular do figurino, dando-lhe uma dimensão estatuária. Para a encenação de Paravents, Genet pede a Roger Blin uma suntuosidade de tal forma que esses figurinos "não estariam em seu lugar nos ombros dos vivos" (1968, p. 222). É bem uma beleza de morte que Genet imagina para essas "vestimentas terríveis". Uma beleza de morte que talvez não seja sem evocar a mistura de medo e fascinação que Genet sentiu diante das estátuas de Giacometti e que lembrou a sensação vivenciada diante de uma estátua egípcia de Osiris (cf. GENET, 1979, p. 42). O corpo trajado que Genet imagina deve vincular-se ao poder das estátuas.

A intuição de Genet por uma estreita correspondência entre estátua e corpo trajado é extremamente justa. Esta correspondência, Michel Serres analisa em seu livro Statues, onde apresenta um subcapítulo intitulado "Costumes" (SERRES, 1987, p. 184). Ali ele propõe um conjunto de reflexões que esclarecem de maneira singular 0 universo teatral de Genet em sua relação com a escultura através do corpo vestido. Evocando o que chama de retórica do traje, Michel Serres relaciona a religião, o exército e o direito com o teatro para o qual, segundo suas palavras, "eles convergem" (1987, p. 186), juntando a retórica do vestuário trágico na sua relação com a dimensão da morte. Foi a figura trágica de Fedra que Michel Serres escolheu analisar, uma Fedra "ídolo petrificado pelo cosmético", "como se o cosmético preparasse a agonia. A toga e a máscara trágica abrandam, solidificam, artigos de morte, esculpem o personagem, eis a estátua" (SERRES, 1987, p. 186). Uma estátua que Michel Serres coloca em relação com a vestimenta das estátuas dos deuses no Egito. Assim, de alguma maneira se estabelece uma filiação da estátua ao corpo trajado. Se "a escultura, a mais arcaica das artes, nos leva ao trágico, à morte, às múmias e deuses" (1987, p. 187), o traje representa um dos últimos estratos do duro para o suave. Daí a idéia de uma "série (que) progride das variedades duras às brandas". Da rocha de onde sai a estátua de pedra "para terminar nos signos da escrita, passando pelo tecido, varição média, meio dura, meio macia" (p.187). Finalmente, para Michel Serres: "o que é uma estátua, se não um corpo vestido?" (1987, p. 189). O véu, o tecido, "mistura de duro e suave: objeto ainda, signo já ; signo ainda, objeto já" ( $p$. 191).

Corpo-signo, corpo-objecto, esta é Warda, de Les Paravents (Os biombos). Efígie adornada antes e para a entrada na morte, 
através de seu corpo trajado ela aspira alcançar a imagem perfeita e definitiva oferecida em sua apoteose antes do desaparecimento. Sob as túnicas de Warda, a morte está "tranquilamente ao trabalho" (GENET, 1979, p. 45) e são eles que podem fazê-la acessar a imagem perfeita: "Trabalhei para não ser, na minha noite, apenas uma espécie de manequim dourado" (1979, p. 310). Um corpo-signo, um corpo-objeto, uma estátua. Nas primeiras cenas de Balcon, os corpos atores prontos, trajados, em grandes dimensões marcam a ruptura com o mundo cotidiano, o mundo real e a entrada neste espaço de liberdade que é o da morte. 0 bispo com sua capa dourada que o "preserva do mundo" (1968, p. 45), o General que "não arrasta atrás (de si) nenhum contingente", acessam "este minuto próximo da morte", onde, especifica - General, "eu não serei nada mais refletido no infinito que minha imagem" (1968, p. 60). O corpo trajado, verdadeira estátua, refletido no espelho, atinge a beleza da morte da imagem em que se desdobra e se cumpre.

Nas estátuas de Giacometti, o que fascina Genet é o movimento que ele percebe da matéria em direção à invisibilidade. É a aliança da materialidade mais dura e a imaterialidade da sombra. Este é o paradoxo da arte do escultor. Uma arte dura e não fluida, mas ao mesmo tempo "dotada do estranho poder de penetrar nesse domínio da morte, de exalar talvez através dos muros porosos do reino das sombras" (Genet, 1979, p. 47). Arte do visível e da materialidade animada por um movimento para a invisibilidade, este é o teatro para Genet. Um teatro em que o ator, corpo-matéria e corpo-fantasma, estátua e sombra-reflexo cristaliza o paradoxo.

O corpo trajado do ator-estátua se faz reflexo no olhar do espelho, como se a essência do ator se situasse, para Genet, nesta tensão entre materialidade e imaterialidade, eco da relação imemorial entre a pedra e a sombra. De ambos os lados, seja esculpido ou refletido, Genet inroduz o corpo do ator no campo da imagem. Por meio de uma espécie de ultraje de simulacros, Genet reafirma que, para ele, a beleza no teatro não é acessível ou perceptível senão pelo acesso ao status da imagem. É, sem dúvida, com o texto do Funambule que esta questão encontra uma das suas expressões mais fortes. O funâmbulo, diz Genet, deve vir da morte, essa morte que precede a sua aparição e que significa o desapego do mundo, das contingências da vida real - o mesmo desprendimento que ele percebe no gesto do escultor Giacometti e que ele exige ao ator do teatro. Consagrar-se à morte, recusar-se a ser "devolvido para a nossa vida", é o que resulta de um funâmbulo "decidido a todas as belezas, capaz de tudo" (GENET, 1979, p. 12). É o que faz significar que a imagem pode aparecer. "Que sua pessoa se reduza cada vez mais para deixar cintilar sempre mais brilhante esta imagem na qual eu digo que um morto habita. Que, enfim, ele não exista senão em sua aparição." (1979, p. 14). Somente o distanciamento do mundo lhe permite "mostrar-se em sua apoteose" (1979, p. 26), uma apoteose que é a da imagem. "Se você alcançá-la essa imagem é a Festa" (1979, p. 21). Uma festa que Genet põe aqui explicitamente em relação à festa que deve representar para ele a performance teatral, essa festa noturna "a mais importante, a última, algo muito próximo de nossos 
funerais" (1979, p. 24) ${ }^{2}$. E o texto de Funambule é constantemente atravessado por um jogo de relações entre imagem, morte, túmulo, apoteose e aparição. Encontramos assim todo o vocabulário e o campo semântico de Balcon e muitos outros textos de Genet.

Certamente não há um espelho concreto diante do qual o funâmbulo dançaria. No entanto, o tema do cara a cara com a imagem, que intervém como um duplo do corpo do dançarino, é um tema que está no cerne do texto. "Nada o impedirá de dançar pela sua imagem" ou ainda "é sua imagem que vai dançar por você" (1979, p. 12). E Genet introduz a referência - ainda que breve - a Narciso, como se a lembrança distante desse mito antigo, que fala de solidão e fascínio pela imagem refletida, cruzasse o texto de maneira subterrânea. Um mito inseparável da problemática do espelho em relação à beleza e à morte. Tudo se passa como se ressurgisse no universo de Genet algo desse antigo imaginário habitado pela "morte no espelho"3. Através dos três espelhos antigos - 0 espelho de Gorgo, o espelho de Narciso, o espelho do templo de Lycosoura - que são objeto de seu livro, Jean-Pierre Vernant e Françoise FontisiDucroux (1997) mostram que se joga a relação com a morte e com o invisível, assim como em Genet a estátua e 0 espelho estão intimamente associados.

O espelho "instrumento de mediação de todos os invisíveis" (1997, p. 195), no templo de Lycosoura reflete as estátuas das deusas. É a esse reflexo de efígies que o fiel é confrontado. Questionando o significado desse estranho dispositivo, os autores do livro se perguntam:

\footnotetext{
2 Sobre este tema ver L'Étrange mot d' (in GENET, 1968).

3 Expressão empregada por Vernant e Frontisi-Ducroux no livro Dans l'oeil du miroir (1997).
}

\begin{abstract}
A mediação suplementar que introduz o espelho tem como objetivo acentuar a distância que separa o divino da percepção que os fiéis podem ter? Ou a transmutação em puro reflexo das pesadas efígies visa dissolver a materialidade marmoreal para restituir à divindade sua essência impalpável? (VERNANT e FRONTISI-DUCROUX, 1997, p. 196)
\end{abstract}

Em todo caso "a disposição deste espelho num contexto cultural busca provocar, por um artifício engenhoso, o equivalente a uma epifania" (idem). Uma epifania associando a estátua e o reflexo no espelho: não é este o horizonte que Genet deseja dar ao trabalho do ator? Uma epifania que reúne poderosos simulacros que vinculam, na antiguidade, a estátua e o espelho. Destaque-se aqui, uma vez mais, que em seu fascínio pela escultura de Giacometti, Genet retoma algo de muito antigo.

Mais do que o sentido do termo epifania, é o sentido de aparição que se acha constantemente sob a escrita de Genet. E é uma epifania de ausência que está envolvida nesta aparição. "Bloco de ausência", que "não existe senão em sua aparição" (GENET, 1979, p. 14), tal como resulta da ação do funâmbulo e também do ator. Trata-se de esculpir a ausência - paradoxo que não é senão um acontecimento teatral que se refere à escultura e ao monumental significando um movimento em busca da ausência, em busca da invisibilidade. No texto Fragments, Genet evoca o monumental do túmulo, mas um monumental que não encerra nada. A aventura fúnebre a que ele aspira, destinada à construção de uma "civilização espectral" (GENET, 1990, p. 92), se desenrola em torno de um catafalco vazio no qual se desenvolve 
um "simulacro" "em honra de toda ausência" (1990, p. 89). É ao seu redor que se constitui, como em Les Nègres, o aparelho da cerimônia teatral é construído.

Para esculpir essa ausência, o teatro trabalha com os atores e seus corpos, mas também com as palavras. "Com meu cinzel frio, separadas do idioma, as palavras, em blocos límpidos, são também túmulos" (1990, p. 82). Estas são as palavras que Genet coloca na boca dos atores, um ato que, outra vez, ele associa à escultura ${ }^{4}$. $O$ gesto poético do escritor subjaz ao gesto poético do ator. Por fim, o que se joga é sempre o refúgio "numa região solitária fora do alcance, a lenda" (1990, p. 70), esta região a que os personagens de Balcon (O Balcão) ou Solange, ao final de Bonnes (As Criadas), sonham se juntar. Esta região que o próprio Genet deseja alcançar escrevendo o Diário de um ladrão (GENET, 1949, p. 126). O uso da lenda é indissociável de uma escrita "capaz de te cinzelar" que está na "busca de alguma posição onde a morte te define" (GENET, 1990, p. 71). A lenda, algo para cinzelar quem se refere à estatuária, ao monumental em sua relação com a poesia e com a noite.

No final de seu texto dedicado a Giacometti, Genet (1979, p. 66-67) detém a imagem do humano como "objeto" em sua solidão total, objeto indestrutível e inalterável cuja solidão diz respeito à nossa. A estátua num pedestal de solidão, um corpo-objeto que não é qualquer objeto. "Algo de vivo e de morto simultaneamente" (GIACOMETTI, 1990, p. 71) denota o próprio Giacometti, o que, para Genet, se refere a "este ponto final onde a vida se assemelha a matéria inanimada" (GENET,

4 Ver mais acima a citação de Michel Serres na passagem do duro para o suave, da pedra para a linguagem, para as palavras.
1979, p. 62). Para o homem de teatro, assim como para o escultor, é aventurando-se à beira da morte, ao lado da pedra e da sombra, que $o$ artista pode magnificar o humano, em sua glória e solidão.

Recebido em: 06/12/2017

Aceito em: 15/01/2018

\section{Referências Bibliográficas}

CRAIG, Gordon. L'acteur et la surmarionnette. In: De l'Art du théâtre. Paris : Ed. Circé, 1999.

DIDI-HUBERMAN, Georges. Le danseur des solitudes. Paris : Ed. de Minuit, 2006.

GENET, Jean. Fragments... et autres textes. Paris : Ed. Gallimard, 1990.

GENET, Jean. Le funambule/L'atelier d'Alberto Giacometti. In: Oeuvres complètes Tome V. Paris: Ed. Gallimard, 1979.

GENET, Jean. Lettres à Roger Blin/'Etrange mot d'. In: Oeuvres Complètes Tome IV. Paris : Ed. Gallimard, 1968.

GENET, Jean. Le journal d'un voleur. Paris : ed. Gallimard, 1949.

GIACOMETTI, Alberto. Ecrits. Paris : Hermann, 1990.

SERRES, Michel. Statues. Paris: Ed. François Bourin, 1987.

VERNANT, J. P.; FRONTISI-DUCROUX, Françoise. Dans l'oeil du miroir. Paris : Ed. Odile Jacob, 1997. 